\title{
MOTHER TONGUE OF ROMA CHILDREN FROM SPECIAL SCHOOLS
}

\author{
Hristo Kyuchukov ${ }^{1}$, William New ${ }^{2}$ \\ ${ }^{1}$ University of Silesia in Katowice \\ 12, Bankowa str., Katowice, 40-007, Poland \\ ${ }^{2}$ Beloit College \\ 700, College str., Beloit, WI 53511, USA
}

\begin{abstract}
The article presents research demonstrating that Roma children placed in special schools for 'defective' children in post-communist countries suffer not from learning disabilities or mental retardation, but from the tendency of such schools to misclassify minority students on the basis of their language knowledge. The research was done with Roma children from Bulgaria, Czech Republic and Slovakia. Results from data suggest that Roma children, with appropriate bilingual educational methods, can achieve proficiency in both Romani and official school languages.

The children in the study (all together 111) - pupil in the first grade from Bulgaria, Czech Republic and Slovakia, are tested with language comprehension test translated to national languages of the countries and to the Romani dialects spoken by the children in the respected countries. The testing was done in the school environment with each child separately (the first week in Romani and the second week in the official language). The results show that the children perform the test better in the official languages of the countries. The Bulgarian children show best results in both languages, the children from Slovakia know better Slovak, but they also have good knowledge in Romani and the children from Czech Republic show good results in Czech but very low results in Romani.

The study shows that the system for selecting the minority children to special schools in those countries should be changed. In Czech Republic and in Slovakia still the Roma children are tested with culturally inappropriate tests only in the official language of the children. There is no testing in their mother tongue. The knowledge of the children in their mother tongue is not considered important.
\end{abstract}

Key words: Roma, bilingualism, defectology, language education

\section{Introduction}

In the educational systems of most post-communist European countries there still exist so called "special schools" for children with putative physical and psychological disabilities. In different languages and different places, these schools were named differently, and served somewhat different purposes. In most of these countries, they were called helping schools. The establishment of these schools in the Soviet sphere was based on existing institutional structures, and ideological/conceptual commitments, in Russia, all under the name of 'defectology'. The field of defectology was developed by Russian psychologists in the first decades of the $20^{\text {th }}$ century as a descriptive, quantitative science, and then given a very different turn by L.S. Vygotsky (1987), articulated most fully in his Fundamental problems of defectology. As later commentators (Grigorenko, 1998, for example) have pointed out, the institutionalization of defectology in Russia and elsewhere 
owes perhaps more to the rigid, normative psychology of psychological scientists who preceded and followed Vygotsky than to Vygotsky himself, with whom the term tends to be associated. In no situation is this more true than with respect to Romani students, whose placement in special schools, and whose diagnoses of 'defect' seems to fulfill social and political agendas, more than represent the principled application of Vygotskian concepts.

In its fundamental conception, defectology is concerned with defects, normally conceived of as fundamental alterations (with negative consequences) of the physical, including neurological, structures of an individual. 'To be technically precise', Gindis (1999, p. 331) maintains, 'In Russia this term covers the following disabilities ... children who are deaf or hard of hearing, children who are visually impaired or blind, children with mental retardation, and children who are speech-language impaired'. In Russia and in post-communist Europe, each 'defect' is associated with a specific pedagogy, and whenever possible individuals (whether students or adults) are segregated into institutions, or at least spaces within institutions, that focus on their specific defects. It's important to note, with respect to the Roma situation, that learning disabilities, emotional disturbance, and the kinds of developmental language delays associated from cultural mismatches between home and school, are not part of original purview of defectology. Though, as we see, it was for these suspect purposes that defectology was mobilized in the case of the Roma.

The term 'defect' is understood in the West as derogatory, but considering a broader history, it's not clear why defect should be considered more disrespectful of a class of persons that it's synonyms 'disability' and 'handicap', each which has its own unfortunate history. In fact, defectology in its original inception as a statistical science of deviance (Kozulin, 1990) was indebted to the same American and Western European psychological science of normativity and pathological deviance that would eventually be deformed into the Nazi version of eugenics. According to this version of defectology, bilingualism among minority children (like the Roma) could be interpreted as a permanent, physiological (i.e. genetic) defect, insofar as they appear not able to learn the official language. The tests administered to these children are written in the official language, and can only confirm that the children have defect. This practice had perhaps its most chilling application in the dissertation of Eva Justin (1943), who was a main actor in the Racial Hygiene and Demographic Biology Research Unit of Nazi Germany's Criminal Police. Justin administered (in a decidedly unscientific manner) a variety of cognitive and linguistic measures, in German, to Sinti/Romani, for whom German was a second language, 'proving' (among other things) that these children "could not think logically, could not concentrate on the tasks, and were genetically predisposed to be criminals" (Kyuchukov and Weiß, 2017). Among the other things Justin's examinations were taken to prove that these children could be under German eugenics law, sent to Auschwitz. Raising the specter of genocide might seem inappropriate in this context, but it is essential to appreciate the historical continuity - under the banner of defectology and special schools - between the educational fate of Romani children in Nazi Germany and their ongoing educational fate in post-communist Europe.

For Vygotsky, the education of children with 'defects' was conceptualized in a completely different way. The 'deficit' model by which institutionalized defectology 
operates - similarly to special education for 'disabled' students in the US - starts with the premise that the defective or disabled children function are lesser versions of normal children, with few if any prospects of 'becoming normal'. Romani children, for instance, are often thought of by their non-Romani teachers as constitutionally unable to succeed academically, and are therefore trained, in the best cases, for low level vocations. Vygotsky understood the handicapped child to experience the world in a qualitatively different manner, by virtue of a different organization of his or her cognitive, motor, linguistic, or sensory apparatus, with a focus on the assets that these children possess, and ways in which they compensate for the ways in which the world is not constructed with them in mind. In many respects, our research seeks to re-invoke his original vision of how cultural and physical difference ought to be approached to, in the context of the bilingualism, and the cultural-historical distance between Roma and non-Roma.

\section{Theoretical background}

Still today, Roma children constitute the majority population in special schools, and special classes, because of their lack of knowledge in the official language of the country, and/or the sociocultural mismatch between their home and school environments, which itself reveals - in the eyes of school authorities - a defect in communication. Each country has established special commissions that test Romani children's knowledge, but the testing materials are nearly always only in the official language of the country, and often they are culturally biased. There are seldom tests or interviews in the mother tongue of the children as well, and rarely are Romani individuals members of these commissions examining and testing children. The issue of minority children being overrepresented in special schools it is not new. Harry and Klingner (2006) reported that in the USA the children are placed in special schools based on their English language test results. The important factors the educators and the school psychologist describe are the time of arrival of the child to USA, his involvement in bilingual program, what kind of support he receives at home or at school.

According to Cummins's (1984) theory there is a difference between cognitive academic language proficiency and basic interpersonal communicative skills. The teachers and the psychologist observe if the child is still learning the formal academic language, or the child's difficulties are caused by other factors. Harry and Klingers (2006) maintain that it is "notoriously difficult to differentiate between normal second language acquisition and learning disabilities $\langle\ldots\rangle$. This distinction is particularly problematic among the children who do not seem strong in either their native language or English" (p. 117). According to the authors it is easier to identify the students with learning disabilities when they are in a bilingual program. Due to the bilingual program the teachers and school psychologist easily can identify if the children's problems are due to the confusion of learning a new language or it is due to some psychological problems. Looking at some of the ECHR cases involving Romani children in special schools, there was simply the presumption of disability when Romani children who were not proficient in the language of school, and whose knowledge of Romani was not perceived to constitute authentic linguistic knowledge, insofar as Romani itself was not regarded as a language, but rather as some kind of jargon, secret code, pidgin or 'ethnolect'. 
But in the districts where Romani children attend school, it is common practice to diagnose bilingual children as learning disabled, when their proficiency in their second language, the language of the school, is not as developed as that of their mother tongue, i.e. Romani, which is not - for the purpose of schooling - considered to be a 'real' language (see Horvath \& Kiss v. Hungary, 2011, a European Court of Human Rights case, for a full description of this process.).

Recently Kyuchukov, de Villiers and Tabori (2017) in a publication about the necessity of testing Roma children in their mother tongue, argue that the assessment of the children's knowledge in their mother tongue is needed to avoid the miss placement of the children in special schools. If the children know different grammatical categories such as tense and aspect of the verb system, possessiveness, wh-questions, passive verbs in their mother tongue, but do not know them in the official language of the country, that must be interpreted as that the children are normally developing. However, the parents are an important factor in the process of mother tongue/home language learning. In some cases where there are Spanish-speaking parents encouraging their children to speak their home language, their children show developmental delays in both Spanish and English. However, in the study of Haitian Creole, researchers found out that when parents think that English is more important for their children than Creole, their home language suffers (Harry and Klingers, 2006). Samko (2017) reports a similar phenomenon with Romani-Slovak mothers who do not value the knowledge or use of Slovak, which tends to inhibit the development of their children's proficiency in the language of the school.

Many years ago, when the first author was working at the Bulgarian Ministry of Education as an expert of Romani language, he heard a somewhat different argument from Roma parents who were more supportive of their children's learning of English (the first foreign language in Bulgaria that time - some 20 years ago) instead of learning Romani as a mother tongue. Their argument was that their children know Romani language well enough, and that this knowledge is not useful in making a career. Harry and Klinger (2006, pp. 122-123) report that the schools in which the bilingual issues are understood better, children's language needs, and the influence of their limited proficiency on learning and behavior, are approached in a constructive, culturally sensitive manner.

According to Winzer and Mazurek (1998, p. 94), "the educational system does not serve all students equally well; school systems nationwide continue to afford negative differential treatment to youth and their families from culturally and linguistically diverse backgrounds". Different studies in USA showed that, mirroring the situation for Romani children, "language minority children are often placed in special educational classes because of their limited English proficiency, not as a result of being disabled $\langle\ldots\rangle$. The schools often make a direct link between a child's English assimilation and the child's economic and social mobility. Students who spoke a language other than English were frequently viewed as handicapped" (Winzer and Mazurek, 1998, p. 95). The authors' further analyses show that limited English proficiency children make up an unusually high proportion of special education classes. In the past the children from migrant and minority groups were overrepresented in USA special schools, classified as mentally retarded. Today the number of linguistic minority students placed in disabilities programs is still growing disproportionally (Morgan et al., 2015). Many factors contribute to the 
overrepresentation of culturally and linguistically diverse students in special classes and one of them is the discriminatory assessment practices which exist in the American schools (Winzer and Mazurek, 1998).

When the same situation was documented in the Czech Republic in 2014, the High Commissioner for Human Rights of the Council of Europe recommended that special schools be closed down, and to introduce inclusive education for Roma children in regular schools (Report of discrimination, 2014). To date, though, little has changed, except special schools are now called vocational schools. The Open Society Institute (2007) estimates that in Bulgaria, $51 \%$ of the children in special schools are Roma, and in Serbia $32 \%$ of the Roma children are in special schools for children with intellectual difficulties (OSI Report, 2010). However, it is obvious that in most of the cases the children have deficits in the official language and at the same time there is no testing of the children in their mother tongue.

\section{Method}

Participants. Roma first-graders enrolled in special schools in Bulgaria, Czech Republic and Slovakia were tested in Romani (as their mother tongue) and in the official language of the country at the end of the school year. All children are provided with literacy instruction in the respective official languages of the schools, but the children also received lessons and after-school activities in Romani with trained Romani language mediators, who had the task of helping the children translate from Bulgarian, Czech, or Slovak to Romani and the other way around.

The number of the children examined is the following:

- 26 children from Bulgaria (Sliven, Vratsa and Blagoevgrad);

- 48 children from Czech Republic (Prague, Brno, Kladno and Ostrava);

- 37 children from Slovak Republic (Spishska Nova Ves, Zhiar nad Hronom, Rozhnava, Koshice, Yarovnitse).

All children included in the study are with Roma origin, speakers of different varieties of Romani language.

Technique. The children were tested in Romani and in the official language of the country with comprehension and production test of 9 grammatical categories. The test is not standardized for Romani and for the official languages of the countries where Roma children live. The content of the test is as it is shown on the following picture (Fig. 1) and the question which would be asked from the children would be: The boy is painting the chair. Show me where it is that?

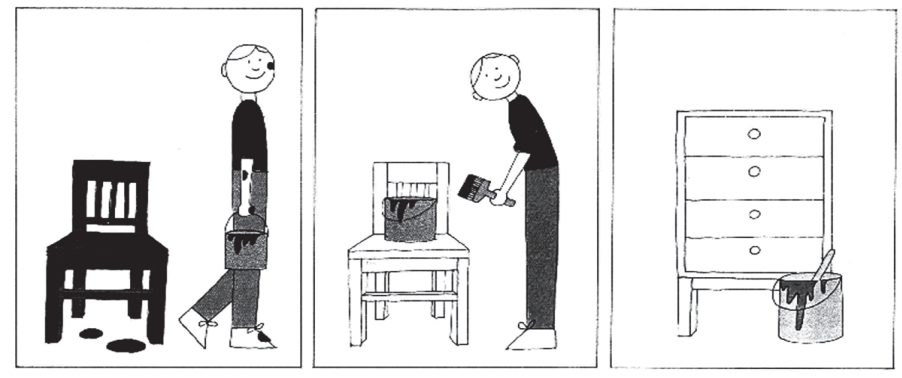

Fig. 1. Sample test task 


\section{Hypothesis:}

H1: Roma children do not have defect, but they have language deficiency in the official language.

$\mathrm{H} 2$ : Their language ability is organized differently because they have Romani as a mother tongue and they are bilinguals by birth.

The research questions which this study aims to answer are:

- Is it possible that the children are mis-placed in the Special schools because they do not know the official language of the country?

- Do the children understand the tests equally good in BOTH Romani and in the official language of the countries?

\section{Results}

The Roma children from three countries in generally show better results in the official language of the country and lower results in Romani. This shows the effect of the Roma school mediators. It is obvious that after one-year work with the children, they improved their knowledge in the official language and the differences between the test performance in both languages - Romani and the official language of the country are statistically significant $F(1.128)=5.4988 ; p=0.02057$. The results are shown in Fig. 2 .
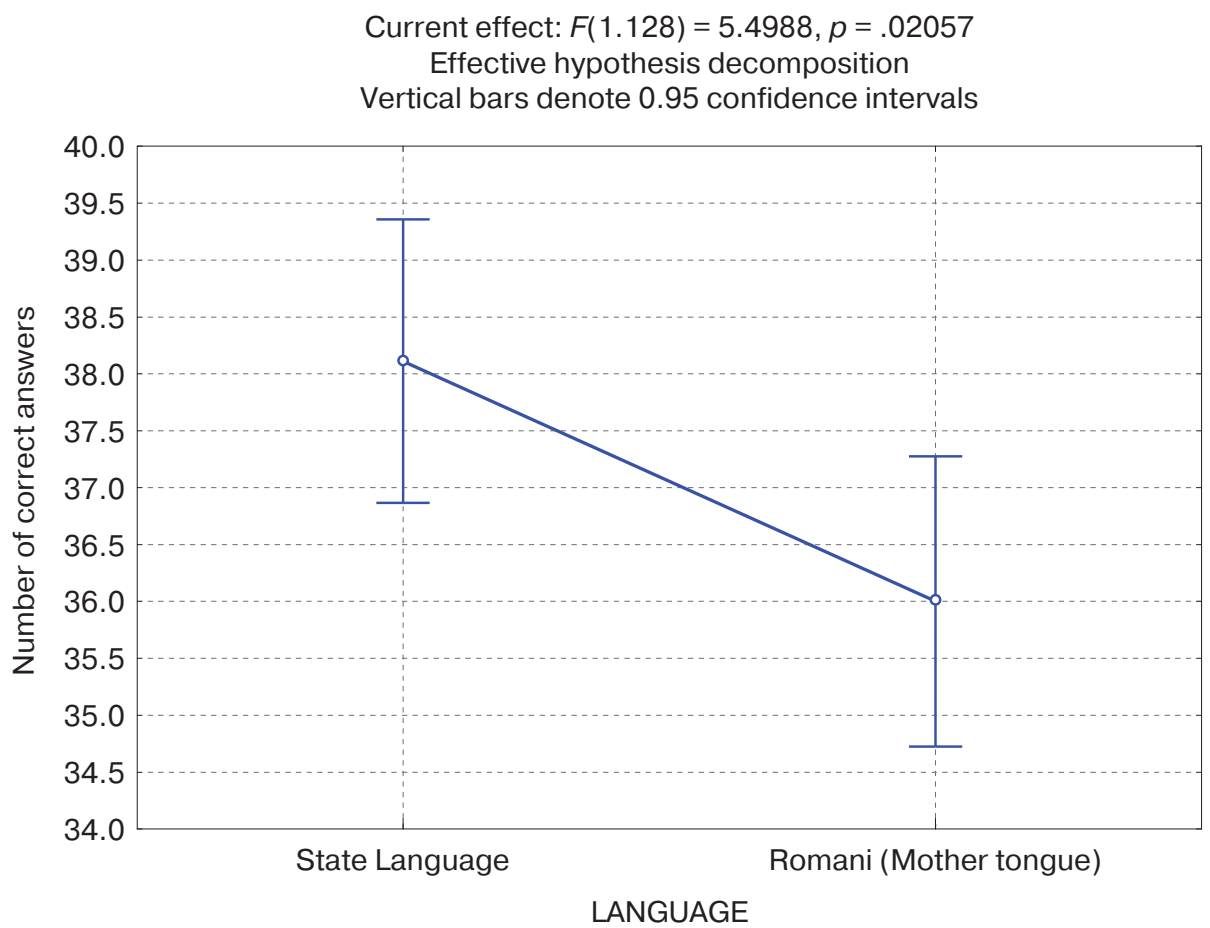

Fig. 2. The performance of the Test by language

Comparing the answers of the children by country it is clear that the Roma children from Bulgaria have highest results, followed by Czech Roma children and Slovak Roma children. The differences are statistically significant $F(2.128)=5.5089 ; p=0.00507$. This is shown in the next Fig. 3. 


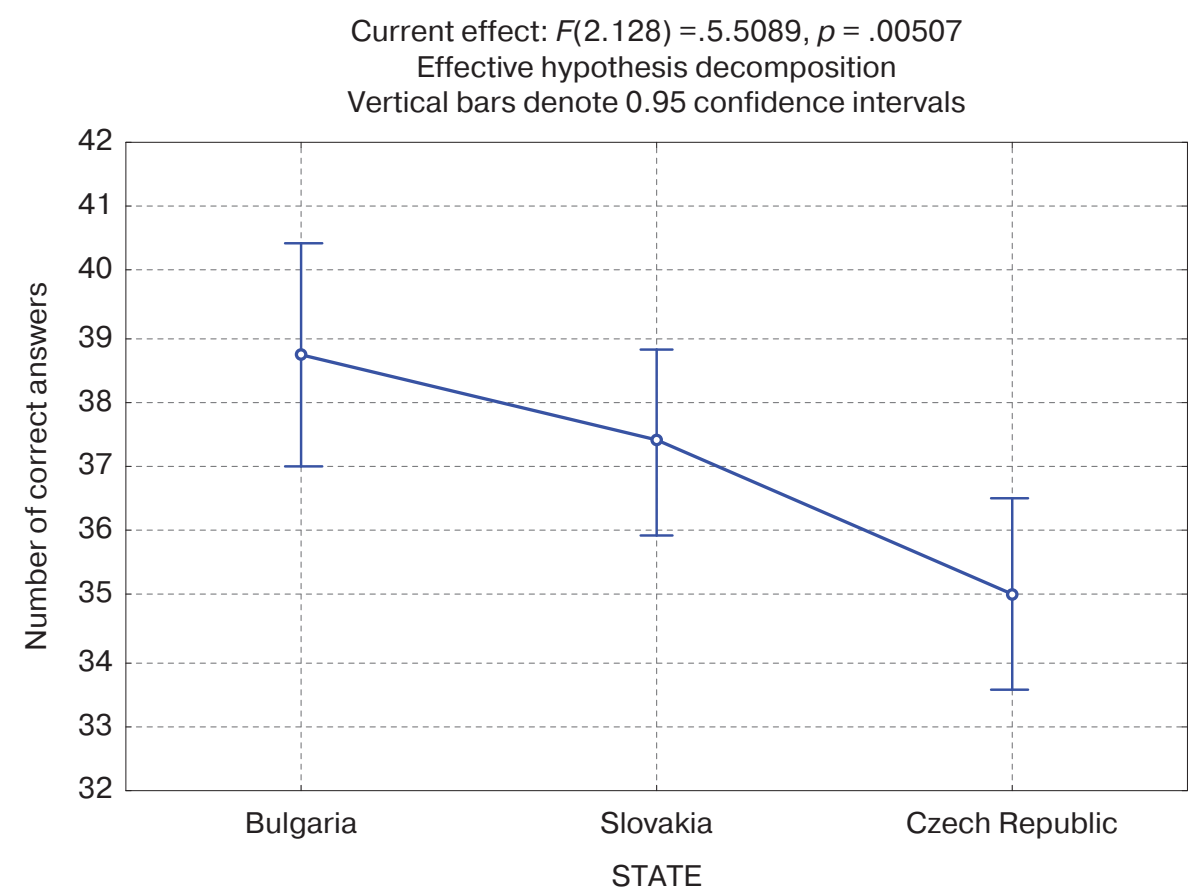

Fig. 3. Performance of the language Test by states

There is a high correlation between the two factors "number of correct answers" and "answers in Romani and in state languages". The correlation is statistically significant $F(2.128)=6.1637 ; p=0.00278$. The percentage of correct answers in the official languages of the countries is higher than in Romani and the differences are highest in the group of Roma children form Czech Republic. This is shown in the next Figure 4.

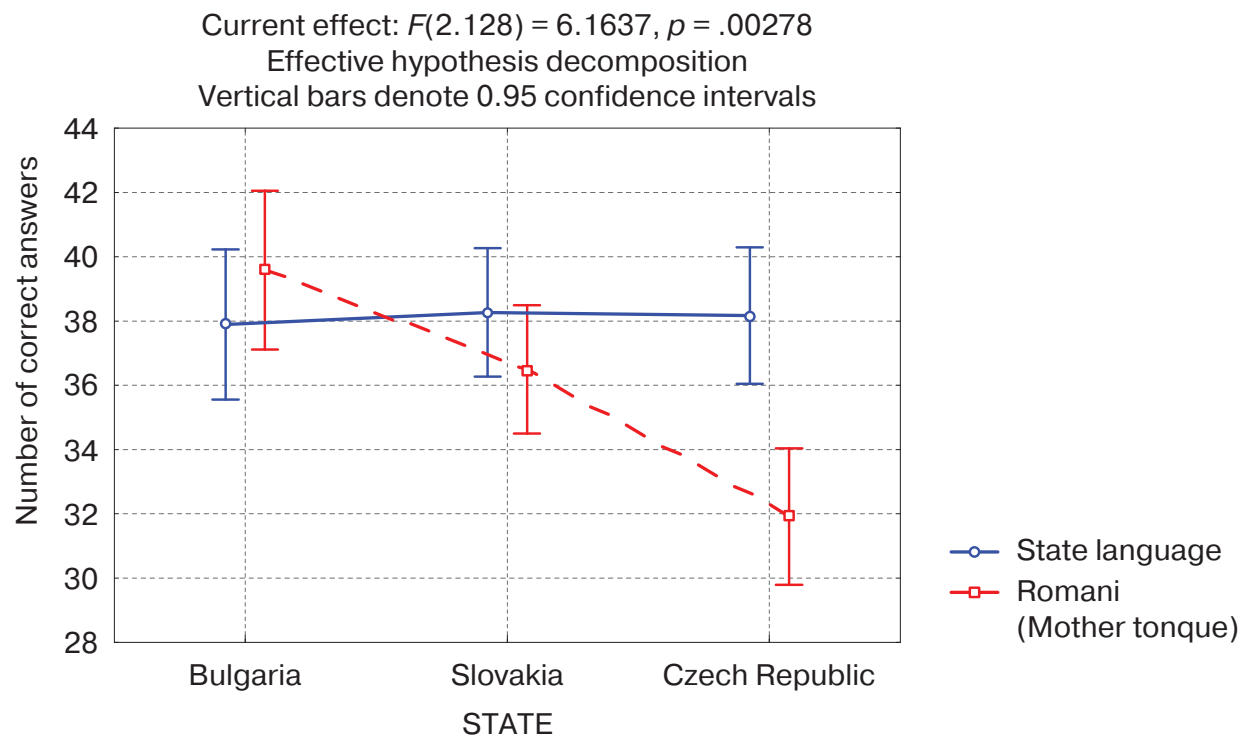

Fig. 4. Correlation between factors "number of correct answers" and "answers in Romani and in state language" 


\section{Discussion}

In Bulgaria, Czech Republic and in Slovakia the bilingualism of the children is treated as a problem and not as an advance for the child. It is very much possible that the Roma children from the special schools at the beginning of the school year did not know and did not understand anything from the official language of the country. This could be one of the reasons for their misplacement in special schools. The presence of a Roma school mediators helps to improve the knowledge of the children in both languages, but in order to get results similar to those of American bilingual children there is a need of introducing bilingual programs in special schools, where the Romani language and culture will be part of the curriculum. Then we can expect different level of knowledge of the children and different attitude towards their bilingualism.

The Results of Czech Roma children in Romani are very low, because the Roma community in Czech Republic almost lost the Romani due to the mass murder of Roma during WWII. The Roma children in Czech Republic speak an ethnolect of Czech language - that includes elements of Romani and non-standard forms of Czech - and not the same Czech spoken by the majority population; this is the reason why the children do not to understand the language of the psychologist who is administrating the tests. So, it is clear that the children are placed in special schools for reasons other than mental retardation or learning disability. As Winzer and Mazurek (1998) stated language minority children are often placed in special educational classes because of their limited language proficiency, we think this is the case with Roma children. The "science" of defectology reduces in practice to only a socio-political strategy to perpetuate Roma social exclusion, and to disadvantage and stigmatize Roma children in schools.

\section{Conclusions}

Although this study is limited, it does show some important tendencies still existing in the educational systems of East and Central European countries. Roma children are diagnosed with learning disabilities or mental retardation, sometimes also with emotional disturbance, but in most cases these children do not have any defect or disability; they have only a knowledge and performance deficit in the official language of the country due to the fact that they have been brought up in Romani language environments. Thanks to the fact that there was testing also in Romani the children could show the knowledge in their mother tongue which is a strong evidence that they have limited language proficiency in the official language and not mental retardation. These deficits in the knowledge can be overcome with compensatory programs or with the help of bilingual teachers/school mediators, speakers of the mother tongue of the children. The knowledge of the bilingual children is differently organized in comparison with monolingual children. One of the languages always takes a dominant role, and usually the bilingual speakers are better in that language. Usually this is the mother tongue and the second language/the official language of the country is learned later. The presence of an adult who belongs to the community helps the both language to develop equally. A properly Vygotskian framework, through which teachers might better understand the assets and perspectives that Roma children bring to school would be a better pedagogical approach than the 
framework currently in use, in which the Roma children's knowledge of Romani language and their cultural heritage are considered liabilities.

It is obvious that the educational systems in East European countries for Roma children should be changed. The way of testing which is practiced now in some East European countries is totally wrong - before entering first grade the children are tested with psychological tests in the official langauge of the country. If a Roma child did not attend a kindergarten and did not learn the official language of the country before to start school, testing him/her with psychological test in the official language (which the child does not know) is not taken as a language deficit issue but as a psychological problem and this is why so many children are sent to schools for children with mental disabilities. In these countries still the lack of knowledge in the official language by minority children is considered as a mental retardation and this is totally wrong. The research here showed that the Roma/bilingual children need a different methodology, different approach to language education. This was proven by the fact that when many Roma children from Slovakia and Czech Republic immigrated to England and were placed in mainstream classes, from students with mental disabilities in Slovakia and Czech Republic, they turned to be just normal students in English schools.

\section{REFERENCES}

Cummins, J. (1984). Disabling minority students: Power, programs and pedagogy. Toronto: Ontario Institute for Studies in Education.

Gindis, B. (1999). Vygotsky's vision: Reshaping the practice of special education for the 21st century. Remedial and Special Education, 20(6), 333-340.

Grigorenko, E. L. (1998). Russian "defectology": Anticipating Perestroika in the field. Journal of Learning Disabilities, 31(2), 193-207.

Harry, B. \& Klingers, J. (2006). Why are so many Minority students in Special Education? Understanding Race \& disability in school. NY: Teachers Colleague Press.

Horváth and Kiss v. Hungary, Application no. 11146/11, Council of Europe: European Court of Human Rights, 29 January 2013, available at: http://www.refworld.org/cases,ECHR,511cf1982. html (accessed 4 December 2017).

Justin, E. (1944). Lebensschicksale artfremd erzogener Zigeunerkinder und ihrer Nachkommen [The Life History of Alien-raised Gypsy Children and Their Descendants]. Veröffentlichungen aus dem Gebiete des Volksgesundheitsdienstes. Schriftenreihe aus dem Arbeitsgebiet der Abteilung Volksgesundheit des Reichsministeriums des Innern. LVII Band - 4 Heft. Berlin.

Kozulin, A. (1990). Vygotsky's psychology: A biography of ideas. Cambridge, MA: Harvard University Press.

Kyuchukov, H., de Villiers, J., \& Tabori, A. (2017). Why Roma children need language assessment in Romani. Psychology of language and communication, 21 (1), doi: 10.1515/plc-2017-0011

Kyuchukov, H. \& Weiß, J. (2017). Educational research regarding Sinti children in Nazi Germany and its consequences in contemporary Europe. In H. Kyuchukov \& W. New (Eds.), Languages of resistance: Ian Hancock's contribution to Romani Studies (pp. 326-342). Munich: Lincom.

Morgan, P.L., Farkas, G., Hillemeier, M.M., Mattison, R., Maczuga, S., Li, H., \& Cook, M. (2015). Minorities are disproportionately underrepresented in special education: Longitudinal evidence across five disability conditions. Educational Researcher, 44(5), 278-292. doi: $10.3102 / 0013189 \times 15591157$ 
Open Society Institute (2007). EU monitoring and advocacy program: Equal access to quality education for Roma. Vol. 1. Bulgaria, Hungary, Romania, Serbia. Budapest: Open Society Institute.

OSI Report (2010). Roma children in "Special Education" in Serbia: overrepresentation, underachievement and impact on life. NY: OSI.

Samko, M. (2017). Linguistic ideologies of Roma mothers and languages of their children. In H. Kyuchukov \& W. New (Eds.), Languages of resistance: Ian Hancock's contribution to Romani Studies (pp. 354-362). Munich: Lincom.

Vygotsky, L.S. (1987). The collected works of L.S. Vygotsky, Volume 2: The fundamentals of defectology. Edited by R. Rieber and A. Carton. NY: Springer Science and Business.

Winzer, M. \& Mazurek, K. (1998). Special education in multicultural context. Upper Saddle River, NJ: Prentice-Hall.

(C) Kyuchukov H., New W., 2018

This work is licensed under a Creative Commons Attribution 4.0 International License

Article history:

Received 19 June 2018

Revised 10 July 2018

Accepted 16 July 2018

For citation:

Kyuchukov, H., New, W. (2018). Mother Tongue of Roma Children from Special Schools. RUDN Journal of Psychology and Pedagogics, 15(3), 323-333. doi: 10.22363/2313-1683-2018-15-3-323333

\title{
Bio Notes:
}

Hristo Kyuchukov - Ph.D. in Education, Dr. Sc. Of Education and Linguistics, Professor of General Linguistics, University of Silesia in Katowice (Katowice, Poland). E-mail: hkyuchukov@ gmail.com

William S. New - Ph.D. in Education and Psychology, Professor and Chair, Department of Education and Youth Studies at Beloit College (Beloit, USA). E-mail: newb@beloit.edu

\section{РОДНОЙ ЯЗЫК ЦЫГАНСКИХ ДЕТЕЙ ИЗ СПЕЦИАЛЬНЫХ ШКОЛ}

\author{
Х. Кючуков ${ }^{1}$, В. Нью ${ }^{2}$ \\ ${ }^{1}$ Университет Силезии в Катовице \\ Польша, 40-007, Катовище, Банкова ул., 12 \\ ${ }^{2}$ Колледж Белойта \\ США, 53511, Белойт, Колледж стрит, 700
}

В статье представлены результаты исследования, свидетельствующие о том, что цыганские дети, помешенные в специальные школы для «неполноценных» детей в посткоммунистических странах, страдают не от неспособности к обучению или умственной отсталости, а от тенденции таких школ ошибочно классифицировать учащихся из числа меньшинств на основе их знания официального языка, на котором ведется преподавание в школе. Исследова- 
ние проводилось с цыганскими детьми из Болгарии, Чехии и Словакии. Результаты свидетельствуют о том, что цыганские дети, обучающиеся с использованием соответствующих двуязычных методов, могут достичь хорошего уровня владения как цыганским, так и официальным школьным языком.

В исследовании приняло участие 111 цыганских детей - учеников первых классов из Болгарии, Чехии и Словакии. Диагностика проводилась с использованием теста на знание языка, переведенного на национальные языки стран, и на диалекты цыганского языка, на которых говорят дети в соответствующих странах. Тестирование проводилось в школе, с каждым ребенком отдельно (сначала на цыганском диалекте, а через неделю - на официальном языке). Результаты показывают, что все дети лучше выполняют тест на соотвествующих официальных языках, чем на цыганском. При этом цыганские дети в Болгарии показывают лучшие результаты на обоих языках, дети из Словакии лучше знают словацкий язык, но также достаточно хорошо знают цыганский, а дети из Чехии показывают хорошие результаты на чешском языке, но очень низкие результаты на цыганском.

Исследование показывает, что следует изменить систему отбора детей из числа меньшинств в специальные школы в изученных странах. В Чехии и в Словакии до сих пор дети цыган тестируются только на официальном языке, на их родном языке тестирование не предсмотрен, так как знания детей на их родном языке не считаются важным.

Ключевые слова: цыгане, билингвизм, дефектология, языковое образование

\section{История статьи:}

Поступила в редакцию: 19 июня 2018

Принята к печати: 16 июля 2018

\section{Для цитирования:}

Кючуков X., Нью В. Родной язык цыганских детей из специальных школ // Вестник Российского университета дружбы народов. Серия: Психология и педагогика. 2018. Т. 15. № 3. C. 323-333. doi: 10.22363/2313-1683-2018-15-3-323-333

\section{Сведения об авторах:}

Кючуков Христо - доктор педагогических наук, Ph.D., профессор Университета Силезии в Катовице (Катовице, Польша). E-mail: hkyuchukov@gmail.com

Нью Вилльям - Ph.D., профессор, профессор и глава департамента образования и исследований молодежи Колледжа Белойта (Белойт, США). E-mail: newb@beloit.edu 